\title{
Transhumanisms: A Review of Transhumanist Schools of Thought
}

\section{Piero Gayozzo}

\begin{abstract}
Transhumanism is a philosophical system that proposes the use of advanced technologies directly in the human body to modify and improve its biological condition. That is the core idea of transhumanism and it can be adopted by various ideological systems in different ways. It will depend on their ethical approach and what they define as "improvement". In this article we will quickly review the difference between transhumanist philosophy, Transhumanism and Transhumanisms.
\end{abstract}

Keywords: Transhumanism, Posthumanism, Archeofutourism, Biohacking, Technological Singularity.

\section{Introduction}

Transhumanism is a philosophical system whose main idea is the use of advanced technologies for the modification of the human body and the human condition. But, Is the modification of human beings enough to achieve the transhumanization of humans? The answer is no. The first goal of transhumanism is to guide the evolution of the human species through technological advances, that is, it seeks to enhance human's bodies through the overcoming of its physical, physiological and psychic limitations. It seeks to improve the human condition radically. However, the idea of "improvement" that lies in its human enhancement proposal may vary according to the school of thought that adopts the main idea of transhumanism.

\section{Transhumanist Philosophy}

The Transhumanism developed by Humanity Plus (former World Transhumanist Association) is based on science and reason. Science is a set of articulated knowledge that is recursively renewed thanks to the scientific method. As a consequence of the accumulated descriptive knowledge, the technique becomes scientific and that is how technologies arise. Technology is neutral and it will depend on how we use it to increase social welfare or serve to contrary purposes. Therefore, it is important to resort to a moral guide to identify what is right and what is not.

There are many ways in which human beings have articulated their moral systems. Some of these are based on supernatural entities and their ordinances (divine revelations); others put passion, myth and heroism above reason; some emphasize selfishness and others absolute collectivism. The question that arises is which of all of these moral systems do we have to choose? As all of them are based on particular beliefs, it is important to look for an ethical system compatible with the objective description of reality, in this case: science. 
Can science help us to discover what is right? Many authors answer yes (Bunge, 1989; Kurtz, 2007; Harris, 2010). From the description of reality (what it is) we can create propositions and axioms about good and right (what should be). The ethical system that has the greatest compatibility with science is Secular Humanism, a system that inherits the values of the Enlightenment and respects the values of science and science itself.

That is why we will distinguish between Transhumanist Philosophy, Transhumanism and Transhumanisms in this text. The Transhumanist Philosophy refers to the central idea of transhumanism: "Use available technologies to modify human biology." (Gayozzo, 2019, p.5) While Transhumanisms will be all those ideological approaches that pick up or add the central idea of Transhumanist Philosophy to their own belief system, which in general includes ethical proposals, policies or social projects.

What we will call from now as Transhumanism $(\mathrm{H}+)$ is the transhumanist school adopted by Humanity Plus, which is built on Secular Humanist ethical system, is Enlightenment-rooted, and proposes the use of advanced technologies to improve the human condition, mainly looking for superlongevity, superintelligence, and super welfare for everybody (Bostrom, 2005). This is the main school of Transhumanist Philosophy, but it is not the only one, as we will see below.

\section{Archeofuturism}

During the 60s the New Right was created in France. This movement was run by several people interested in the work of the German Conservative Revolution and the intellectual fruits of fascism. Their objectives were to face globalisation, offer an alternative to the policies that allows immigration, miscegenation and cosmopolitanism and recover the undermined European culture and race. Those were the core values of what would be called as the Fourth Political Theory. Among its highlighted thinkers we can found Guillaume Faye, author of archeofuturism. His work proposes the rejection of the values of modernity and the Enlightenment (progress, freedom and equality), since he considers them as responsible for the decline of Europe. To achieve his goals, he invites us to reconsider some archaic or premodern ethical system to guide a new social order (a European Empire) that would be capable to adapt to the technological changes of the contemporary world. In such a way, archeofuturism accepts the use of bio technologies to improve the biological condition of the Empire's elite and as a mean to guarantee the numerical increase of the European ethnic population (Faye, 2010). At the end of the book and in its sequel, the novel Archeofuturism 2.0, Faye explains the way in which human enhancement bio technologies would be used according to his imagination.

Heir of romantic and mythical thinking, archeofuturism is a transhumanist proposal of the conservative sector and of the followers of the Fourth Political Theory because it rescues the main idea of transhumanism from a different ethical system (Gayozzo, 2019a) as part of a radical right project. (Monzocco, 2019)

\section{Body Hacking (Grinder)}

Biohacking's popularity was unleashed after Rob Carlson's "Splice it Yourself" article in Wired magazine of 2005. It was a short manual to set up a low cost and homemade molecular biology research laboratory. Years later, a group of these scientists would include biology to the many disciplines or activities labeled under the popular Do-it-Yourself trend. The increasingly massive Internet movement would ensure the democratization of knowledge and online advice on new biological procedures. By adding the ideal hacker, Bio-Hacking 
(Biology + Hacking) would arise.

Body Art supporters would pay special attention to Transhumanist philosophy and together with Bio-Hacking enthusiasts they would form a sub-culture whose purpose would be to experiment with the human body to add new functions or to connect their bodies to the physical-digital ecosystem of their homes. This movement would be called Grinder or Transhumanist Body Hacking current.

Hacker ethics, different from what is usually believed, does not appeal to cyber hacking, but rather points to cooperation and the democratization of knowledge. Body Hackers are trained on the Internet and bet on experimentation with themselves (selfexperimentation) since they resort to skin manipulations and even minor surgeries to place sub-dermal magnetic implants, bio-sensors and bio chips with which to achieve humanelectronic communication (Yetisen, 2018), greater interaction with information technologies available in their home spaces (open doors, store information, etc.) as well as to have greater monitoring and control of their health status. (Nye, 2018)

\section{Cishumanism}

The most popular positions in the debate on human enhancement are the extreme ones: bioconservatism and transhumanism; but there exist some nuances that are little considered. In 2014 Ashely Dustin posted a note on the Humanity Plus blog in which he coined the term Cishumanism to identify a trend that, from his perspective, was more cautious than transhumanism.

Inspired by cis-trans chemical isomerism nomination, Cishumanism is a movement that shares the same values as transhumanism, with the exception that it promotes human enhancement as a strategy to be carried out only with reparative motives, that is, preserving human identity without exceeding its capabilities and using technology to solve need or lack problems, not to make a wish of transcendence come true. (Dustin, 2014)

Although the difference seems subtle, this transhumanist approach abandons the utilitarianism of the classical transhumanist ethics to adopt a pragmatic moral system. From that approach Cishumanism tries to solve need/desire and practicality/fantasy dilemmas that could be found in political and theoretical transhumanism. That is why it defines itself as a practical transhumanism (transhumanism made practical) with the "goal of creating solutions for real-world problems." (Ashley, 2014, para. 5)

Its defenders propose Cishumanism as an alternative to transhumanism and bioconservatism. However, in this small group different views are distinguished. While Dustin accepts limited human enhancement, Fiala presents it as an overcoming of political and social bioconservatism because, unlike this, it celebrates sexual and human diversity. (Fiala, 2019)

\section{Cyborgism}

The cyborg, or cybernetic organism, is an entity composed of organic material to which digital elements have been added. Initially it was an idea proposed as a solution for the logistical problems of space exploration. Given that our species requires specific environmental conditions to survive and simulate them in extraterrestrial spaces would be a hard task, scientists Manfred Clynes and Nathan Kline proposed that in the future the technology will be used to create self-regulated man-machine systems (Clynes \& Kline, 1960). This system would incorporate technological components to the biological organism to adapt it to different scenarios that could compromise the life of the explorer (oxygenation, 
vestibular function, changes in pressure or force of gravity, etc.). The original idea of the cyborg, far from the myth of feminine liberation developed by Haraway, appeals to an utilitarian ethics approach according to which human enhancement is allowed through adaptations to specific scenarios, but not necessarily as means to achieve greater intelligence or longevity. Cyborgism has a core idea: to merge the biological reality with cybernetic one. This idea is also a type of human enhancement, which can be seen today. The credit goes to the appearance of intelligent prostheses and disciplines such as biomechatronics.

\section{Chimerism / Para-humanism}

Para-humanism is a term that includes the possible individuals that result from genetic crosses between human beings and animals. The most remote origins of this idea can be traced to mythological and fantastic narratives of ancient cultures, while its most contemporary expression can be found in H. G. Wells' novel The Island of Doctor Moreau.

We can identify two varieties of parahumanism: uplift, used in science fiction to describe a parahuman created by the anthropomorphization of a non-human animal (Transhumanism Fandom, s.f.) and biological trans-speciesism (Tomlinson, 2020), an adaptation of a human to a hybrid entity, both by technological means.

In the bioethical discussion, the use of the medical term chimerism predominates over that of uplifts. These organisms are the product of the insertion of human genes in non-human animals in order to be used for various medical purposes. (Lu, Zhou, \& Chen, 2019)

The second conception of para-humanism refers to the inclusion of non-human animal genes in humans and other forms of human-animal hybridization (Doyle, 2018). In particular, Savulescu (2003) supports the idea of enhancing human capacities by including animal characteristics that increase our reasoning and even sensory capacities such as night vision or echolocation.

The visible communities that could be most directly linked to this trend are the other kin movement and the theriantrope community (Nøkken, n.d.). Both communities identify themselves as alter humans or individuals other/different than humans. The former identifies themselves as mythological creatures, while the latter perceives themselves as animals. (Scribner, 2014)

This last group has proposed the use of future technologies such as mind uploading or neuralink to obtain terianthrope morphs (terimorphs), avatars or animal-human organisms controlled by a mind remotely (Michael Hrenka, 2017). Another activist community of parahumanism is the furry one. At the Eurofurence 17 Furry Convention in 2011 the furry movement presented an exhibition that explored the creation of furries (anthropomorphized canines) through genetic engineering, in vitro fertilization and selective breeding of animals, as well as the conversion of humans into furries using tissue engineering and 3D printing. (Vilkatas, 2011)

The ideas of chimerism or para-humanism are marginal trends in transhumanism, but not for that reason with little potential for future debate.

\section{Extropianism}

Extropianism was founded by Max More in the 1990s. It is defined as an individualist and libertarian version of transhumanism that proposed a post-democratic model of society (More, 2003) guided by an anarcho-capitalist orientation that would guarantee the necessary and unrestricted order and freedom for the continuous improvement of individuals. The 
attention that extropianism focused on the free market as a social engine turned with the passage of time towards a moderate approach like the one presented in the third version of the extropian principles, one compatible with the values of an open society rather than an anarcho-capitalist order. (More, 1998)

According to extropianism, self-transformation is a process that increases extropy, a factor contrary to entropy that measures intelligence, vitality, energy and other fundamental resources for the functioning of an organism. By placing this value at the core of its philosophy of life, it turns the new technological scenario into a path towards the transcendence and improvement of our limited humanity (More, 1993). Deprived of a supernatural and divine reality that ties material life to imperfection, extropianism points towards continuity, excellence, a transhuman state that moves away from entropy.

\section{Immortalism}

Perhaps one of the greatest desires of human beings is to live longer. The improvement of drugs, medical care and lifestyle have allowed human beings to live longer than the average of past times. Transhumanism embraces the promises and advances of medical nanotechnology, 3D tissue bioprinting and other biotechnologies to declare the possibility to increase life span. A radical vision of this idea would lead to Immortalism, and more conscientiously to longevism (More, 1993). Biogerontologist Aubrey de Gray is currently the most iconic scientist of longevism. He proposes to consider aging as a disease that must be cured. To this end, he has developed a project called Strategies for Engineered Negligible Senescence that aims to understand the causes of aging, such as chromosomal and mitochondrial mutations, and develop theoretical strategies to reverse them, such as the allotopic expression of genetic proteins (back up genes) (Grey \& Rae, 2007). The effort initiated by de Gray is not the only one in this area. In 2014 the multimillion-dollar company Google founded Calico Labs, a center dedicated to the understanding of the science of aging and the development of procedures that will allow a longer and healthier life for humans (Calico Labs). Immortalism, as a system of thought, proposes a sense of improvement that lies in the lengthening of life and the recovery of youth's health standards.

\section{Techno-Progressivism}

Transhumanist sociologist James Hughes proposed in his book Citizen Cyborg a Democratic Transhumanism, a political version compatible with the principles of the Enlightenment that do not go against or prohibit technological research, instead, it proclaims that it is necessary to take advantage of technological progress to reduce inequality and increase the possibilities of all citizens to achieve a successful life by massifying it and allowing its free use. (Hughes, 2004)

Later, he would name this trend as techno-progressive, regarding the compatibility between this term and its alternative proposal in the biopolitics axis (Hughes, 2009). The emergence of NBIC technologies would open the doors for new debates at the political level. Contrary to bioconservative thinking, techno-progressivism is built on the values of equality, critical thinking, human dignity and social justice. These values allow it to stand at one end of the debate about human enhancement, brain control, and life extension in the new biopolitical spectrum. Advocating for the free use of NBIC technologies, techno-progressivism permits people to control their reproductive rights, bodies and brains at will within a democratic and progressive political framework. (Hughes, 2009)

\section{Transfigurism}

Since 2006 there has been a Mormon Transhumanist Association attached to the world 
transhumanist declaration and that has reaffirmed its adherence to transhumanism because it is an extension of Jesus Christ teachings (Transfigurism, 2019). Because of the compatibility of Mormon values with the ones of transhumanism (humanism, democracy, materialism), the parallelism of their doctrines (transfiguration and singularitarianism) and of its teachings, Mormonism accepts transhumanism as part of its ideas.

According to Mormon narrative, God commanded his children to continue his work through science and technology. For transfigurism, the closest idea to God is a post-human projection, that is why technological advancement allows human beings to accelerate the work of God and Jesus Ministry (make the deaf hear and make the blind to see). Human beings must learn how to become God and how to use technology to obtain an immortal and perfect body (Cannon, 2015). Transfigurism is a variant of transhumanism that approves technological improvements of the human body that are compatible with Mormon doctrine and its ethics.

For transfigurists, immortality or radical life extension would not undermine its principles or alter God's plan. Due to advanced technologies, His plan would accelerate and the need of God instead of decreasing will increase. About mind uploading transfigurism does not believe it as a possible event because there is no dualism in its worldview. According to the Mormon doctrine, God and the spirits are made of matter, and each atom of reality has a part of the soul of God. (Mercer \& Maher, 2014)

\section{Prometheism}

In the 90s within the extropian movement some transhumanists flirted with fascist futuristic thinking and the idea of a Nietszchean-style superhumanism. Holocaust denier Lyle Burkhead would adopt a National Socialist transhumanism according to which the Third Reich would be the only transhumanist state model that ever existed.

In the 2000s, the Xenith.com website founded by "Marcus Eugenicus" was a refugee for a community of transhumanists who exalt white nationalism, seek racialist eugenics and subscribe to fascist ethics and mythical and heroic exaltation over reason.

Another like-minded community promoted Prometheism, a kind of supremacist transhumanism that advocates racialist eugenics practiced by a state with coercive capacity to ensure the existence of a genetically superior race. Prometheism would encourage loyalty and patriotism to a eugenic state and devotion to a new genetically edited higher race goal. (Hughes, 2001)

\section{Singularitarianism}

The Technological Singularity was originally proposed by Google's chief engineer, Raymond Kurzweil. However, Irvin Good's description of machine intelligence exponential explosion is credited as a previous singularity thesis. As we can see, there is no only one Technological Singularity model, other models have been proposed by science fiction writer Vernor Vinge, and self-taught transhumanist philosopher Eliezer Yudkowsky. (Yudkowsky, 2007)

In general, this school of thought has an optimist approach while analyzing the development of technology. According to its principles, it will be possible to create a super artificial intelligence capable of continuously improving and replicating itself. Due to the super-intelligent entity, technological progress will increase rapidly and will help human beings to transhumanize themselves successfully. In this sense, the fusion of man and machine would be achieved and, as a consequence, it will be possible for conscious life to saturate the Universe. Basically, the singularity is proposed as a context, a stage of the 
development of intelligence in the Universe that will arrive sooner or later on the subject of technological advancement and mechanisms for computing and processing information. (Kurzweil, 2005)

\section{Supermuslim}

The religious tradition of Islam is considered by many to be one of the most orthodox and contrary to progress, especially due to the rise of radical movements that in modern times have hit the West with terror and blood. Although it is not possible to find an Islamic transhumanist group because of the previous reason, some authors suggest that it would be possible to find a link between Islam and transhumanism.

In Muslim and Supermuslim (2020), Roy Jackson, Reader in Philosophy of Religion, reviews the link between the Islamic vision of the Perfect Man (insan al-Kamil) and the post human. To do this he focuses his attention on the three stages of being developed by the Pakistani poet Muhammad Iqbal in Secrets of the Self, a thesis that would combine the search for union with Allah with the philosophy of the spirit of Nietzsche and the Law of Sharia. On his own, Prisco (2020) shows that it is possible to interpret some passages of Koran and the Hadith in a compatible way with transhumanism too.

On the other hand, as Mavani (2014) affirms, some variants of Islam such as Salafism, Wahhabism and Hanbalism will hardly include the use of advanced technologies (nanotechnologies, cloning or genetic engineering) and the transhumanist project in their worldview for the same reason that they accept the idea that God's creation (taghyir khalq Allah) should not be modified. It is also for doctrinal reasons that it is proposed to consider Islamic transhumanism as a different form of transhumanism that, unlike appealing to technological advancement as its secular counterpart, calls for human improvement through spiritual means and its closeness to God. (Mobayed, 2017)

\section{Suprahumanism}

In his article "The Overhuman in the Transhuman", the philosopher Max More (2010) evidenced a certain influence of Nietzschean work on transhumanism, as well as the possibility that, far from Enlightenment utilitarianism, a heroic or Nietszchean transhumanism may develop. That is the case of Daniel S. Forrest's Suprahumanism.

Following the ideological line of the alt-right, Forrest develops a philosophy that focuses on Nietzsche's heroism and anti-conformity, on the critique of modernity, the decline of Western Civilization thesis, and the idea of myths as an intuitive force that orders and guides a society towards the fulfillment of its destiny (Forrest, 2014). According to this approach, the myth of globalization will plunge Europe into debacle, that is why it is important for Europe to turn towards suprahumanism myth.

This project accepts the Hediggerian concern that human beings will be overcome by technological development and that it will not be able to adapt to changes, but rejects the divine view that human beings should not be enhanced. Based on the rejection of slave morality, Suprahumanism suggests applying NBIC technologies, genetic engineering, cloning, cybernetics and other tools as engines for the European revolution.

In order to achieve it, Suprahumanism accepts that it is time to end natural selection and start a "conscious evolution." Consistent with the vision of the warrior and the exaltation of the aristocracy, Forrest proposes to turn towards the old technique of "selective breeding" of Spartan origin, but this time guided by biotechnologies means. 
For suprahumanism, technology is a source of power, which, regarding its novelties and advances, requires a new myth to unleash European's vital force. With that recipe, Forrest tries to reconcile technology with philosophy, as it was in classical Greece; the goal: to create a political space for the suprahuman.

According to its Nietzschean roots, "Suprahumanism rejects slave morality myth, which includes the belief and respect of human rights, egalitarianism and the condemnation that a pure ethnic society can govern itself; on the contrary, it goes for an ethical system that accepts the cult of the leader, the heroic individualism and the exaltation of the community and its traditions." (Forrest, 2014, p. 233)

\section{Xenofeminism}

The term Xenofeminism is used for the first time in 2015 by the Laboria Cuboniks collective. The text in which it appears is a manifesto in which Xenofeminism is described as a new form of feminism adapted to the most recent social problems. To do this, it proposes the use of alienation as a path towards a "depetrified" future, not static, that exceeds the standards of "normal" in every sense, could them be economic, political, social or health, including the desanctification of nature in pursuit of the artificial and techno-scientific realms. (Cuboniks, 2015)

Xenofeminism, as Biles says (2019), is Danna Haraway's cyberfeminism heir, as it continues the cyborg metaphor. Like the latter, it proposes a socialist and postmodern scenario of femininity that contemplates a science neither masculine nor Western, a liberating postgenerism status and an overcoming of the nature/culture (artificiality) gap. It defines itself as a techno-materialist, anti-naturalist and abolitionist movement of gender. (Hester, 2018)

Due to its accelerationist roots, it focuses its attention on the use of technology as a transformational mechanism of universals, such as the overcoming of gender, classes and races. For these reasons, xenofeminism adopts the transhumanist thesis, specifically the biohacking and DIY variant to establish that a transformation of technology for self-help purposes is possible, in this it points to female emancipation and, later, to the transformation of the body as a path to overcome of gender and female corporeity (Hester, 2018). The development of DIY biotechnologies is essential to achieve this. These objectives go back to the search for reproductive sovereignty that began with Del Em technology, in terms of menstrual extractions and, more recently, in the bio-hack-activism of xenofeminist gynecology laboratories in which women are trained in the manufacture of devices for the self-inspection of the cervix and vaginal fluid diagnosis. (Valero \& Lage, 2019)

Although it does not define itself as transhumanist, xenofeminism not only includes the thesis of modification of the human body, but it is compatible with Max More's changing and dynamic utopia and Pierce's morphological freedom principle, with the exception that it is limited to female biology .(Pilsch, 2017)

\section{The Transhumanisms (Results and Discussion)}

Transhumanism proposes the use of advanced technologies in the human organism to improve its functionality. What is understood as "better" will be established by the ethical system to which the group that proposes human enhancement goals is attached. This can be so flexible that it varies between utilitarian ethics (Cyborgism), Secular Humanist ethics (Humanity Plus, Techno-Progressivism), some pre-modern ethical systems (Archeofutourism), heroic or Nietzschean ethics (Suprahumanism), Hacker ethics (Body Hacking / Grinder), religious ethics (Transfigurism, Supermuslim) or ethical individualism (Extropianism). 
On the other hand, transhumanist literature also offers a possible context for human enhancement (Singularitarianism), at the same time it has adopted various strategies to be achieved, either through self-training (Body Hacking / Grinder) or through social institutions such as an Empire (Archeofuturism), a Democratic State (Techno-progressivism), a marketdominated society- anarcho-capitalism- (Extropianism), an Intelligent, Digital and Technological State called Post-Democracy (Gayozzo, 2020), marxist accelerationism (Xenofeminism) or an authoritarian coercitive State (Prometheism). Regarding the permissibility of human enhancement, some could be named as more conservative (Cishumanism) as some others could be catalogued as more extremists (Chimerism).

Confidence in its realization also oscillates between a quasi-religious excessive optimism, as is the case of Singularitarianism, worthy of harsh criticism (Centro de Estudios Crisolistas, 2019; Chace, 2018); an unconventional proposal such as Immortalism, branded as pseudoscientific by some authors (Estep, y otros, 2006); as well as a scenario with possible technological risks that must be evaluated in a skeptical, rational, cautious and attentive way (Humanity Plus).

Science and technology are good or bad as long as they serve a specific purpose. Transhumanist philosophy has as its main idea the use of advanced technologies to enhance and improve human condition. However, as the idea of improvement depends and changes according to the moral system adopted by an individual or a movement, and because there are many social means to achieve human enhancement, transhumanist philosophy suffers an adaptation of its main idea by thevarious ideological systems. These changes give rise to multiple forms of transhumanism or, what is the same, the appearance of Transhumanisms. Despite this difference, transhumanism is still understood as the family of transhumanisms as a whole.

\section{References}

Ashley, D. (2014). Cishumanism: Transhumanism Made Practical (opinion). http://transhumanity.net/cishumanism-transhumanism-made-practical/

Benítez, Valero. L., \& Pin, Lage. P. (2019). Un laboratorio para una gin(eco)logía Xenofeminista. https://cajanegraeditora.com.ar/blog/un-laboratorio-para-unaginecologia-xenofeminista/

Biles, J. (2019). Xenofeminism: A Politics for Alienation. Manifesto. By Laboria Cuboniks. 2018. Religious Studies Review, 45(1), p. 62. https://doi:10.1111/rsr.13824

Bostrom, N. (2005). A History of Transhumanist Thought. Journal of Evolution and Technology, 14(1), pp. 1-25. https://www.nickbostrom.com/papers/history.pdf

Bunge, M. (1989). Treatise on Basic Philosophy. Volume VIII. Ethics: the good and the right. Kluwer Academic Publishers.

Calico Labs. (n.d.). Mission \& Values. https://www.calicolabs.com

Cannon, L. (2015). What is Mormon Transhumanism. Taylor \& Francis in Theology and Science.

Centro de Estudios Crisolistas. (2019). Al día de hoy la posmodernidad, entendida no solo como estadio temporal sino también como sistema de creencias y declaraciones. [Post]. Facebook. www.facebook.com/centrocrisolista/photos/a.163594884161890/636507270203980?t ype $=3 \&$ sfns $=$ mo

Chace, C. (2018). Artificial Intelligence and the Two Singularities. CRC Press.

Clynes, M., \& Kline, N. (1960). Cyborgs and Space. Astronautics,5(9), pp. 26-27.

de Grey, A., \& Rae, M. (2007). Ending Aging. The Rejuvenation Breakthoughs that could reverse human aging in our lifetime. St. Martin Press. 
Doyle, D. J. (2018). What Does it Mean to be Human? Life, Death, Personhood and the Transhumanist Movement. https://doi:10.1007/978-3-319-94950-5

Dustin, A. (2014, July 9). Cishumanism. Humanity Plus Magazine. https://hplusmagazine.com/2014/07/08/cishumanism/

Estep, P. W., Kaeberlein, M., Kapahi, P., Kennedy, B. K., Lithgow, G. J., Martin, G.M., Melov, S., Powers, R. W., Tissenbaum, H. A. (2006). Life Extension Pseudoscience and the SENS Plan. MIT Technology Review. https://www2.technologyreview.com/sens/docs/estepetal.pdf

Faye, G. (2010). Archeofuturism: European Visions of the Post-Catastrophic Age. Arktos Media Ltd.

Fiala, A. (2019). A Defense of Cis-Humanism: Humanism for the Anthropocene. Essays in the Philosophy of Humanism, 27, pp. 1-20. https://americanhumanist.org/wpcontent/uploads/2019/10/art-1-Fiala-A-Defense-of-Cis-Humanism-Humanism-forthe-Anthropocene.pdf

Forrest, D. (2014). Suprahumanism: European Man and the regeneration of History. Arktos Media Ltd.

Gayozzo, P. (2019). Arqueofuturismo: El Transhumanismo Conservador. Instituto de Extrapolítica y Transhumanismo.

Gayozzo, P. (2019). La Hipótesis Transhumanista. Instituto de Extrapolítica y Transhumanismo.

Gayozzo, P. (2020). El Estado Post-Democratico. Instituto de Extrapolítica y Transhumanismo.

Harris, S. (2010). The moral Landscape. Free Pass.

Hester, H. (2018). Xenofeminism. Polity Press

Hughes, J. (2001, November 1-4). The politics of Transhumanism [Conference session]. 2001 Annual Meeting of the Society for Social Studies of Science, Cambridge, MA, United States.

Hughes, J. (2004). Citizen Cyborg. Westview Press.

Hughes, J. (2009). TechnoProgressive Biopolitics and Human Enhancement. In J. Moreno \& S. Berger(Eds.), Progress in Bioethics, pp. 163-188. MIT Press.

Jackson, R. (2020). Muslim and Supermuslim. The Quest for the Perfect Being and Beyond. Palgrave Macmillan.

Kurtz, P. (1991). Toward a New Enlightenment. Transaction Publishers.

Kurtz, P. (2007). Science and ethics. Can Science Help us make wise moral judgments? Prometheus Books.

Kurzweil, R. (2005). The Singularity is Near: When Humans Trascend Biology. Viking.

Laboria Cuboniks. (2015). Xenofeminism: A Politics for Alienation. https://www.laboriacuboniks.net/20150612-xf_layout_web.pdf

Lu, Y., Zhou, Y., \& Chen, J. (2019). Human-animal chimeras for autologous organ transplantation: technological advances and future perspectives. Annals of Transnational Medicine, 7(20), p. 576. https://doi:10.21037/atm.2019.10.13

Mavani, H. (2014). Islam - God's Deputy: Islam and Transhumanism. In C. Mercer, \& D. F. Maher (Eds.), Transhumanism and The Body. The World Religions Speak, pp. 67-84. Palgrave MacMillan.

Mercer, C., \& Maher, D. F. (2014). Transhumanism and the Body. The World Religious Speak. Palgrave Studies in the Future of Humanity and its Successors.

Michael Hrenka, R. (2017). Towards Therianthrope Morphs. Fractal Future Forum. https://forum. fractalfuture.net/t/towards-therianthrope-morphs/2243

Mobayed, T. (2017). Immortality on Earth? Transhumanism through Islamic Lenses. Yaqeen Institute for Islamic Research. https://yaqeeninstitute.org/tamim- 
mobayed/immortality-on-earth-transhumanism-through-islamic-lenses

Monzocco, R. (2019). Transhumanism. Engineering the Human Condition. History, Philosophy and Current Status. Springer.

More, M. (1993). Technological Self-Transformation: Expanding Personal Extropy. Extropy \#10. https://thehingeblog.wordpress.com/2017/06/22/technological-selftransformation-expanding-personal-extropy-by-max-more

More, M. (1998). The Extropian Principles Version 3.0. : A Transhumanist Declaration. https://mrob.com/pub/religion/extro_prin.html

More, M. (2003, November 17). Democracy and Transhumanism.Are transhumanists democrats? Should they be committed to and defined by democracy? Cryonet. http://www.cryonet.org/cgi-bin/dsp.cgi?msg=22861

More, M. (2010). The Overhuman in the Transhuman. Journal of Evolution and Technology, 21 (1), pp. 1-4.

Nøkken. (n.d.). The Otherkin/Therian Community Discourse Map. Wild Path Library. https://wildpathlibrary.org/otherkin-therian-discourse-map/

Nye, C. (2018). Biohacker: Meet the people "hacking" their bodies. BBC News. Https://www.bbc.com/news/technology-46442519

Pilsch, A. (2017). Transhumanism. Evolutionary Futurism and the Human Technologies of Utopia. University of Minnesota Press.

Prisco, G. (2020). Tales of the Turing Church. https://docs.google.com/document/d/1G6QgkGNKIEmsqUcnhTtvMRNJ9WTaWC7d-c1UboUze0/edit\#

Savulescu, J. (2003). Human-Animal Transgenesis and Chimeras Might Be an Expression of Our Humanity. The American Journal of Bioethics, 3(3), pp. 22-25. https://doi:10.1162/15265160360706462

Scribner, O. (2014). A Simple Introduction to Otherkin and Therianthropes. Otherkin. https://www.otherkin.net/2016/09/a-simple-introduction-to-otherkin-andtherianthropes/

Tomlinson, G. (2020). Posthumanism. In T. McAuley, N. Nielsen, \& J. Levinson (Eds.), The Oxford Handbook of Western Music and Philosophy, pp. 415-436. https://doi:10.1093/oxfordhb/9780199367313.013.20

Transfigurism. (2019). Mormon Transhumanist Affirmation. transfigurism.org/mormontranshumanist-affirmation

Transhumanism Fandom. (n.d.). Parahuman. https://transhumanism.fandom.com/wiki/Parahuman

Vilkatas, A. (Alfa Vilkatas) (2011, October 10). Creating Furries with BioTechnologies(Video). YouTube. https://www.youtube.com/watch?v=crEvPo8Pozk\&feature=emb_logo\&ab_channel= AlfaVilkatas

Yetisen, A. K. (2018). Biohacking. Trends in Biotechnology. 36(8), pp. 744-747. https://doi:10.1016/j.tibtech.2018.02.011

Yudkowsky, E. ( 2007). Three Major Singularity Schools. Machine Intelligence Research Institute. https://intelligence.org/2007/09/30/three-major-singularity-schools/

\section{$\underline{\text { Bio-note }}$}

Piero Gayozzo is the General Coordinator of Peruvian Secular Humanist Society (Sociedad Secular Humanista del Perú - SSH) and the Founder and Sub-Director of Institute of Extrapolitics and Transhumanism, a research group of SSH. He is also a Member of Peruvian Association of Journalists and Science Communicators (Asociación Peruana de Periodistas y Comunicadores de la Ciencia APCIENCIA) and the Founder and Chief Editor of Future Now (Futuro Hoy) Journal. He has contributed many scientific articles to a popular science 
magazine called $\mathrm{N}+1$. Currently, he is a manager of the SSH's Fourth Industrial Revolution Forum Project in Peru. He has written many philosophical essays.

E-mail: pgayozzo@ssh.org.pe 